\title{
Front Matter: Volume 9439
}

, "Front Matter: Volume 9439," Proc. SPIE 9439, Smart Materials and Nondestructive Evaluation for Energy Systems 2015, 943901 (21 May 2015); doi: $10.1117 / 12.2195412$

Event: SPIE Smart Structures and Materials + Nondestructive Evaluation and Health Monitoring, 2015, San Diego, California, United States 


\title{
PROCEEDINGS OF SPIE
}

\section{Smart Materials and Nondestructive Evaluation for Energy Systems 2015}

\author{
Norbert G. Meyendorf \\ Editor \\ 9-10 March 2015 \\ San Diego, California, United States \\ Sponsored by \\ SPIE \\ Cosponsored by \\ American Society of Mechanical Engineers (United States) \\ Cooperating Organizations \\ Intelligent Materials Forum (Japan) \\ Jet Propulsion Laboratory (United States) \\ National Science Foundation (United States) \\ Published by \\ SPIE
}


The papers included in this volume were part of the technical conference cited on the cover and title page. Papers were selected and subject to review by the editors and conference program committee. Some conference presentations may not be available for publication. The papers published in these proceedings reflect the work and thoughts of the authors and are published herein as submitted. The publisher is not responsible for the validity of the information or for any outcomes resulting from reliance thereon.

Please use the following format to cite material from this book:

Author(s), "Title of Paper," in Smart Materials and Nondestructive Evaluation for Energy Systems 2015, edited by Norbert G. Meyendorf, Proceedings of SPIE Vol. 9439 (SPIE, Bellingham, WA, 2015) Article CID Number.

ISSN: 0277-786X

ISBN: 9781628415421

Published by

SPIE

P.O. Box 10, Bellingham, Washington 98227-0010 USA

Telephone +1 3606763290 (Pacific Time) · Fax +1 3606471445

SPIE.org

Copyright (C) 2015, Society of Photo-Optical Instrumentation Engineers.

Copying of material in this book for internal or personal use, or for the internal or personal use of specific clients, beyond the fair use provisions granted by the U.S. Copyright Law is authorized by SPIE subject to payment of copying fees. The Transactional Reporting Service base fee for this volume is $\$ 18.00$ per article (or portion thereof), which should be paid directly to the Copyright Clearance Center (CCC), 222 Rosewood Drive, Danvers, MA 01923. Payment may also be made electronically through CCC Online at copyright.com. Other copying for republication, resale, advertising or promotion, or any form of systematic or multiple reproduction of any material in this book is prohibited except with permission in writing from the publisher. The CCC fee code is 0277-786X/15/\$18.00.

Printed in the United States of America.

Publication of record for individual papers is online in the SPIE Digital Library.

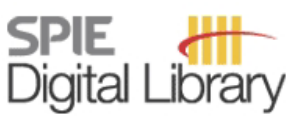

SPIEDigitalLibrary.org

Paper Numbering: Proceedings of SPIE follow an e-First publication model, with papers published first online and then in print. Papers are published as they are submitted and meet publication criteria. A unique citation identifier (CID) number is assigned to each article at the time of the first publication. Utilization of CIDs allows articles to be fully citable as soon as they are published online, and connects the same identifier to all online, print, and electronic versions of the publication. SPIE uses a six-digit CID article numbering system in which:

- The first four digits correspond to the SPIE volume number.

- The last two digits indicate publication order within the volume using a Base 36 numbering

system employing both numerals and letters. These two-number sets start with 00, 01, 02, 03, 04, $05,06,07,08,09,0 A, 0 B \ldots$. OZ, followed by 10-1Z, 20-2Z, etc.

The CID Number appears on each page of the manuscript. The complete citation is used on the first page, and an abbreviated version on subsequent pages. 


\title{
Contents
}

\author{
$\checkmark$ Authors \\ vii Conference Committee
}

\section{KEYNOTE SESSION I}

943902 Needs and opportunities: nondestructive evaluation for energy systems (Keynote Paper) [9439-1]

\section{SESSION 1 NDE FOR NUCLEAR ENERGY}

943904 Phased array ultrasonic testing of dissimilar metal welds using geometric based referencing delay law technique [9439-3]

\section{SESSION 2 GREEN, CONVENTIONAL, AND NUCLEAR ENERGY}

943905 Nondestructive evaluation of thick concrete structures [9439-4]

\section{SESSION 3 WIND AND SOLAR ENERGY}

9439 OA MEMS inertial sensors for load monitoring of wind turbine blades [9439-9]

$9439 \mathrm{OB}$ Structural damage detection in wind turbine blades based on time series representations of dynamic responses [9439-10]

9439 OC Acoustic emission monitoring of wind turbine blades [9439-11]

9439 OD Eddy current imaging for electrical characterization of silicon solar cells and TCO layers [9439-12]

9439 OE Pyro-paraelectricity: a new effect in hetergeneous material architectures [9439-13]

9439 OF Electrospun strontium titanata nanofibers incorporated with nickel oxide nanoparticles for improved photocatalytic activities [9439-35]

\section{SESSION 4 BATTERIES AND FUEL CELLS}

$9439 \mathrm{OH} \quad \mathrm{High}$-performance porous carbon/ $\mathrm{CeO}_{2}$ nanoparticles hybrid super-capacitors for energy storage [9439-15]

9439 ol Porous carbon/ $\mathrm{CeO}_{2}$ composites for Li-ion battery application [9439-16] 
9439 0J Applications of nano and smart materials in renewable energy production and storage devices [9439-17]

\section{SESSION 5 MONITORING AND ENERGY CONVERSION}

9439 OK Using aeroelastic structures with nonlinear switching electronics to increase potential energy yield in airflow: investigating analog control circuitry for automated peak detection [9439-19]

$9439 \mathrm{OL}$ Acoustic signatures of different damage modes in plain and repaired granite specimens [9439-20]

$9439 \mathrm{OM} \quad$ Ultrasonic thickness structural health monitoring photoelastic visualization and measurement accuracy for internal pipe corrosion [9439-21]

9439 ON Developing a structural health monitoring system for nuclear dry cask storage canister [9439-22]

\section{SESSION 6 ENERGY CONVERSION AND HARVESTING}

$94390 Q \quad$ Reliability-based design optimization for nonlinear energy harvesters [9439-25]

9439 OS An experimentally validated parametrically excited vibration energy harvester with timevarying stiffness [9439-27]

9439 OU Experimental investigation of fatigue in a cantilever energy harvesting beam [9439-29]

POSTER SESSION

9439 OV Ultrasonic assessment of tension shear strength in resistance spot welding [9439-30]

9439 OX Investigation of eddy current examination on OD fatigue crack for steam generator tubes [9439-32]

$9439 \mathrm{OZ}$ Electrospun $\mathrm{TiO}_{2}$ nanofibers incorporated with graphene nanoflakes for energy conversion [9439-34] 


\section{Authors}

Numbers in the index correspond to the last two digits of the six-digit citation identifier (CID) article numbering system used in Proceedings of SPIE. The first four digits reflect the volume number. Base 36 numbering is employed for the last two digits and indicates the order of articles within the volume. Numbers start with 00, 01, 02, 03, 04, 05, 06, 07, 08, 09, OA, OB...0Z, followed by 10-1Z, 20-2Z, etc.

Aggelis, D. G., OL

Alarifi, Ibrahim M., OF, OZ

Alharbi, Abdulaziz, OF, OZ

Asmatulu, Ramazan, OF, $\mathrm{OZ}$

Avvari, Panduranga Vittal, OU

Bao, Jingjing, $0 \mathrm{~N}$

Bond, Leonard J., 02, OC, OM

Chen, Huaidong, $\mathrm{OX}$

Chin, Huai-An, OE

Clayton, Dwight A., 05

Cooperman, Aubryn M., OA

Devaraj, Arun, $\mathrm{OH}, \mathrm{Ol}$

Ding, Boyuan, OX

Drosinos, Jonathan G., OK

Eason, Thomas J., OM

Garcia, Ephrahim, OK

Ghandchi Tehrani, Maryam, OS

Ghasemi-Nejhad, Mehrdad N., OJ

Giurgiutiu, Victor, ON

Grayson, Malika, OK

Han, Taeyoung, 04

Hever, Henning, OD

Hillmann, Susanne, 04, OD

Hoell, Simon, OB

$\mathrm{Hu}, \mathrm{Chao}, 0 \mathrm{Q}$

Hwang, Byungguk, OD

lliopoulos, S., OL

Islam, Md. Tariqul, $\mathrm{OH}, \mathrm{Ol}$

Karim, Hasanul, $\mathrm{OH}, \mathrm{Ol}$

Khan, Waseem S., OF

Klein, Marcus, OD

Knight, Travis, ON

Kong, Yuying, OX

Lam, Poh-Sang, ON

Lee, Soobum, 0Q

Li, Ming, OX

Lin, Bin, ON

Lin, Yirong, $\mathrm{OH}, \mathrm{Ol}$

Liu, Jinhong, OX

Liu, Peiwen, OU

Lozev, Mark G., OM

Mao, Sheng, OE

Martinez, Marcias J., OA

Matikas, T. E., OL

McAlpine, Michael C., OE

Meyendorf, Norbert G., 04, OX

Mihalca, Alexander G., OK

Moghanizadeh, Abbas, OV

Mpalaskas, A. C., OL
Nandasiri, Manjula I., $\mathrm{OH}, \mathrm{Ol}$

Noveron, Juan C., $\mathrm{OH}, \mathrm{Ol}$

Ohemeng, Kwaku K., OE

Omenzetter, Piotr, OB

Papakitsos, G. S., OL

Purohit, Prashant K., OE

Rodriguez, Gerardo, $\mathrm{OH}$, $\mathrm{Ol}$

Rustighi, Emiliano, OS

Sandoval, Armando, 01

Schubert, Frank, 04

Schulze, Martin, OD

Schwarz, Ashleigh M., OH, $\mathrm{Ol}$

Seong, Sumin, $O Q$

Shinde, Manish A., $O Z$

Shuvo, Mohammad Arif Ishtiaque, $\mathrm{OH}, \mathrm{Ol}$

Soh, Chee Kiong, OU

Sun, Xiaoyi, ON

Van Dam, Jeremy, OC

Van Hemelrijck, D., OL

Vijayakumar, Murugesan, $\mathrm{OH}, \mathrm{Ol}$

Visweswaran, Bhadrinarayana L., OE

Wagner, Sigurd, OE

Yang, Yaowen, $\mathrm{OU}$

Yu, Lingyu, ON

Zaghari, Bahareh, OS 
Proc. of SPIE Vol. $9439943901-6$

Downloaded From: https://www.spiedigitallibrary.org/conference-proceedings-of-spie on 26 Apr 2023 Terms of Use: https://www.spiedigitallibrary.org/terms-of-use 


\section{Conference Committee}

Symposium Chairs

Victor Giurgiutiu, University of South Carolina (United States)

Christopher S. Lynch, University of California, Los Angeles

(United States)

Symposium Co-chairs

Jayanth N. Kudva, NextGen Aeronautics, Inc. (United States)

Theodoros E. Matikas, University of loannina (Greece)

Conference Chair

Norbert G. Meyendorf, Fraunhofer IKTS-MD (Germany) and University of Dayton (United States)

Conference Co-chair

Theodoros E. Matikas, University of loannina (Greece)

Conference Program Committee

Ali Abdul-Aziz, NASA Glenn Research Center (United States)

George Y. Baaklini, NASA Glenn Research Center (United States)

Leonard Bond, lowa State University (United States)

Michael Dalichow, Quality Network Inc. (United States)

Tae-Young Han, Yonsei-Fraunhofer Joint Medical Device Laboratory (Korea, Republic of)

Peter Heilmann, arxes-tolina GmbH (Germany)

Manfred Johannes, South African Institute for Non-Desctructive Testing (South Africa)

Michael Kroening, Pontifícia Universidade Católica do Rio de Janeiro (Brazil)

Jinhong Liu, China General Nuclear Power Corporation (China)

Alexander Michaelis, Fraunhofer IKTS (Germany)

Bernd Michel, Fraunhofer-Institut für Elektronische Nanosysteme (Germany)

Dong-Jin Yoon, Korea Research Institute of Standards and Science (Korea, Republic of) 


\section{Session Chairs}

Keynote Session I

Norbert G. Meyendorf, Fraunhofer IKTS-MD (Germany) and University of Dayton (United States)

1 NDE for Nuclear Energy

Leonard J. Bond, lowa State University (United States)

2 Green, Conventional, and Nuclear Energy

Leonard J. Bond, lowa State University (United States)

3 Wind and Solar Energy

Dong-Jin Yoon, Korea Research Institute of Standards and Science (Korea, Republic of)

Peter Heilmann, arxes-tolina GmbH (Germany)

Keynote Session II

Norbert G. Meyendorf, Fraunhofer IKTS-MD (Germany) and University of Dayton (United States)

4 Batteries and Fuel Cells

Alexander Michaelis, Fraunhofer-IKTS CMD (Germany)

5 Monitoring and Energy Conversion

Susanne Hillman, Fraunhofer IKTS-MD (Germany)

6 Energy Conversion and Harvesting

Susanne Hillman, Fraunhofer IKTS-MD (Germany)

Norbert G. Meyendorf, Fraunhofer IKTS-MD (Germany) and University of Dayton (United States) 